\title{
Biostratigraphy and palaeoenvironmental analysis of a Lower to Middle Jurassic succession on Anholt, Denmark.
}

\author{
MARIT-SOLVEIG SEIDENKRANTZ \\ Department of Earth Sciences, \\ University of Aarhus, \\ 8000 Arhus C, Denmark.
}

\author{
EVA BUNDGAARD KOPPELHUS \\ Geological Survey of Denmark, Thoravej 8, \\ 1400 Copenhagen NV, Denmark \\ New address: Geological Survey of \\ Greenland \\ Oster Voldegade 10 \\ 1350 Copenhagen K, Denmark
}

\author{
HELLE RAVN-SDRENSEN \\ Department of Earth Sciences, \\ University of Aarhus, \\ 8000 Arhus C, Denmark.
}

\begin{abstract}
Palynomorph and foraminiferal assemblages have been studied from the Upper Pliensbachian to Bathonian of a borehole section on the island of Anholt in the Kattegat, situated near the eastern margin of the Norwegian-Danish Basin. Palynomorphs were recorded throughout the succession and have been used for both biostratigraphical and palaeoenvironmental assessments. Foraminifera were recorded from only the lower part of the succession, where they proved useful for interpreting palaeoenvironments. Four palynomorph and three foraminiferal zones have been established.

The interval encompasses a palaeoenvironmental transition from a marine, inner shelf setting to mainly terrestrial conditions. The Upper Pliensbachian-Toarcian boundary marks the beginning of a major regression, which continued through the Toarcian and Aalenian. Hence, it took place significantly earlier at Anholt than in the centre of the Norwegian-Danish Basin, where a lowering of sea level did not occur until the late Toarcian.

The Jurassic succession on Anholt spans the Fjerritslev and Haldager Sand formations; biostratigraphical data indicate that the Lower-Middle Jurassic boundary is here located within the uppermost part of the Fjerritslev Formation. The Fjerritslev and Haldager Sand formational transition was previously considered to coincide with the Lower-Middle Jurassic boundary. J. Micropalaeontol. 12 (2): 201-218, December 1993.
\end{abstract}

\section{INTRODUCTION}

Jurassic strata were studied from a boring on the small Danish island of Anholt in the Kattegat (Fig. 1). This site is located near the eastern margin of the Norwegian-Danish Basin, which extended across most of Denmark into the present North Sea during the Early and Mid Jurassic. This depocentre continued into the Danish-Polish Trough to the south-east, and was delimited by the Fennoscandian Shield to the north and north-east and by the Ringkobing-Fyn High to the south (Sorgenfrei \& Buch, 1964; Michelsen, 1978; Liboriussen et al., 1987). Our study focuses on the biostratigraphy and palaeoecology of the uppermost Lower Jurassic to Middle Jurassic section.

Previous investigations have revealed a generally regressive phase in the uppermost Fjerritslev Formation. Deposition of open marine claystones occurred during the Pliensbachian and possibly early Toarcian, and of more restricted marine claystones during the late Toarcian (Michelsen, 1989a). Prograding delta or braided river sediments of the Haldager Sand Formation were deposited during the Mid Jurassic in the north-east of the basin (Michelsen, 1978, 1989a; Koch, 1983). The purpose of this study is to provide a biostratigraphic subdivision of the succession using microfossils, and to evaluate the palaeoenvironmental setting at the basin margin.
The succession from $196 \mathrm{~m}$ to $306 \mathrm{~m}$ depth in the Anholt core, consists of marine claystons with numerous very thin silty and sandy storm layers (a few $\mathrm{mm}$ or $\mathrm{cm}$ thick) referred to the Fjerritslev Formation, and from $104 \mathrm{~m}$ to 196 $m$ depth it comprises alternating non-marine sand and silty clay layers with some thin brown coals referred to the Haldager Sand Formation (Fig. 2; Nielsen, 1992).

\section{MATERIAL AND METHODS}

The present study is based on both core material and ditch cuttings from a $306 \mathrm{~m}$ deep boring in the northwestern part of Anholt (Fig. 1). The boring penetrated about $104 \mathrm{~m}$ of Quaternary sediments before it reached deposits of Mid Jurassic age and continued into the upper part of the Lower Jurassic. The elevation of the drilling site is about $2 \mathrm{~m}$ above present-day sea level, and all of the depths noted are calculated below this altitude.

The material from c. $104 \mathrm{~m}$ to $230 \mathrm{~m}$ consists of both cuttings and core samples, while that from the lowest part of the boring (c. $230 \mathrm{~m}$ to $306 \mathrm{~m}$ ) consists solely of core samples (Fig. 2). The lithological log (Fig. 2) was prepared by Ole Bjørslev Nielsen (University of Aarhus). The total organic carbon content (TOC) of the sediments (Fig. 2) was analyzed at the University of Aarhus (AU), and at the Geological Survey of Denmark (DGU) O.B. Nielsen, 


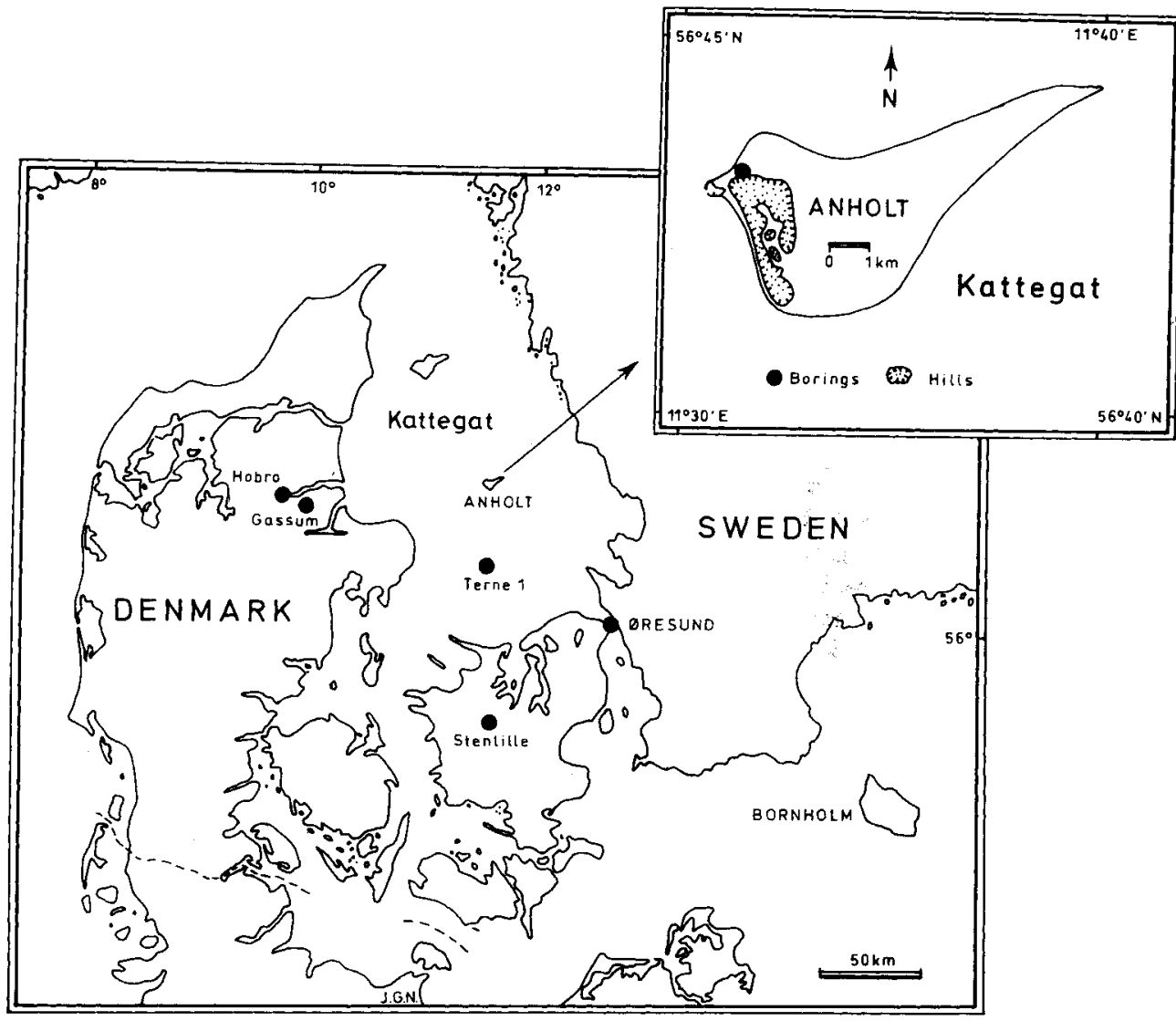

Fig. 1. Map showing the location of boreholes and outcrops mentioned in the text. The inset map of Anholt shows the location of the borehole investigated.

pers.comm 1992; B.J. Smidt, pers. comm. 1992. The spectral natural gamma ray log was measured by Korsbech \& Gynther Nielsen (1990 a, b) (Fig. 2).

Eighty-three samples were analysed for their palynoflora, and 190 samples were examined for their foraminifera and megaspore content, although only 63 and 27 are illustrated on Figures 3 and 4 respectively. Representatives of other fossil groups were also encountered in the microfossil samples: juvenile bivalves and gastropods, ostracods, otoliths, scolecodonts, foraminiferal test linings, animal burrows, ammonites, and a part of a thoracic vertebra from a fish (Fig. 4). Except for megaspores, fossils were only found in 27 of these latter samples.

Palynomorphs. The samples from $306 \mathrm{~m}$ to $229 \mathrm{~m}$ depth were processed at DGU using the technique described by Poulsen et al. (1990). The samples from $229 \mathrm{~m}$ to $107 \mathrm{~m}$ depth were processed at the AU using the technique described by Dybkjaer (1988). Two techniques were used because the palynological analysis was divided between two separate laboratories. Where possible, 300 specimens were counted from each sample. A selection of the palynomorphs recorded is shown in Fig. 3. The palynomorph samples and slides from the lowermost interval $306 \mathrm{~m}$ to $229 \mathrm{~m}$ are stored at the DGU, whereas the samples from the upper interval $229 \mathrm{~m}$ to $107 \mathrm{~m}$ are housed at $\mathrm{AU}$.

Foraminifera and megaspores. The samples for the foraminiferal and megaspore analyses $(100-500 \mathrm{~g}$ of sediment) were processed at AU using standard techniques for foraminifera (Meldgaard \& Knudsen, 1979). All foraminifera and megaspores present in the $0.1-1.0 \mathrm{~mm}$ fraction were counted except for those samples which yielded more than 300 specimens. In these cases only 300 specimens were identified. Selected foraminiferal species are included in Fig. 4 as estimated numbers of specimens per $1000 \mathrm{~g}$ of sediment. The foraminifera are stored at AU and the megaspores at the DGU.

\section{RESULTS}

Palynological zonation

Palynomorphs were recorded from $306 \mathrm{~m}$ to $107 \mathrm{~m}$ (Fig. 3) and a total of 137 species recognised. Two assemblages and two acme zones are defined using the definitions of Hedberg (1976). The boundary between two zones is placed in the interval between two sampling horizons (Fig. 3).

The Nannoceratopsis senex - Nannoceratopsis sp. 1 Assemblage Zone (PA), is the lowermost palynozone (Fig. 3). The assemblage is dominated by dinoflagellate cysts, especially Nannoceratopsis senex (Pl. 1, fig. 3) and Nannoceratopsis sp. 1. (Pl. 1, fig. 5). In the lowermost sample (306 m) one specimen of Luehndea spinosa (C. HeilmannClausen, pers. comm. 1991) (Pl. 1, fig. 1) and one specimen of Mendicodinium reticulatum (Pl. 1, fig. 2) were found. Laevigate trilete spores are common, together with abundant pollen of e.g. Corollina torosus (P1. 3, fig. 2) and Chasmatosporites hians.

The overlying Spheripollenites subgranulatus Acme Zone (PB), is characterized by a diverse pollen and spore flora, a dominance of the pollen Spheripollenites subgranulatus (P1. 2, fig. 10), and a high frequency of S. psilatus (Pl. 2, figs 12 \& 13) and Corollina torosus. The lower boundaty of this zone is defined at the increase in occurrence of $S$. subgranulatus (at $230 \mathrm{~m}$ ). Also typical is the common occurrence of the spores Ischyosporites variegatus (P1. 2, fig. 9), Striatella jurassica, Taurocusporites verrucatus (P1. 2, fig. 2), Foraminisporis jurassicus (Pl. 2, fig. 4), Polycingulatisporites liassicus (Pl. 2, fig. 3), and Campenia gigas (P1. 3, fig. 8) and the occasional presence of the spores Leptolepidites major (Pl. 2, fig. 5), L. 


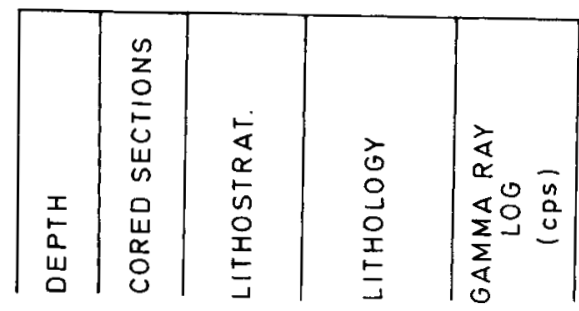

$$
\text { (xem }
$$
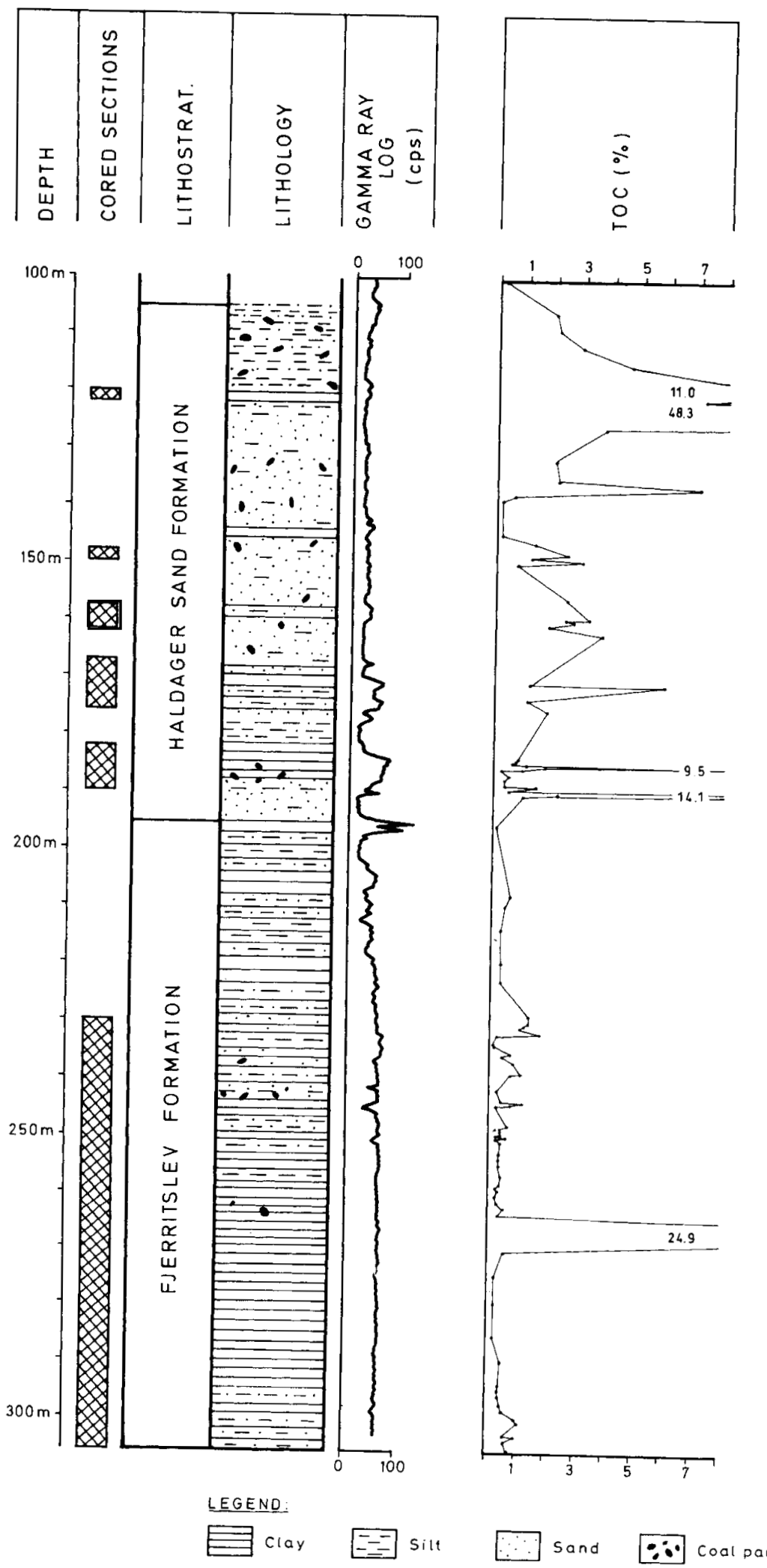
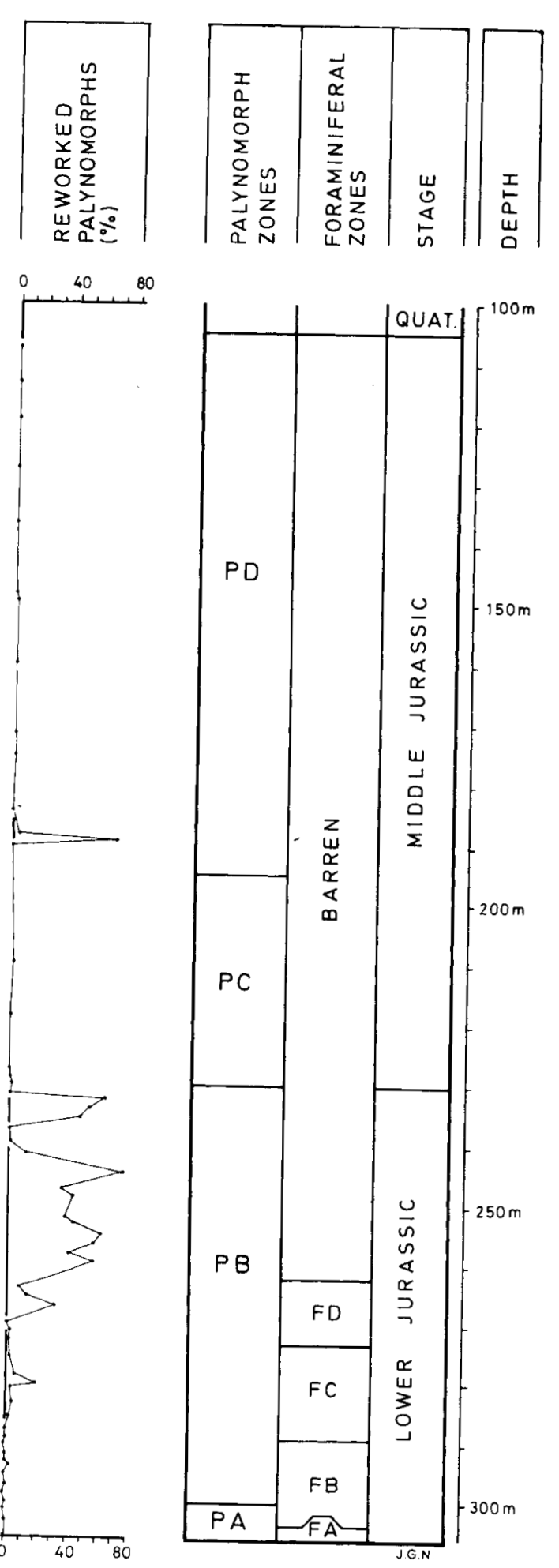

Fig. 2. Lithological $\log$, total spectral natural gamma ray $\log (c p s=$ counts per second), TOC values, and reworked palynomorphs from the lower $200 \mathrm{~m}$ of the Anholt boring (partly after Korsbech \& Gynther Nielsen, 1990a,b; Nielsen, pers. comm. 1992; Schmidt, pers. comm. 1992). 
Seidenkrantz, Koppelhus \& Ravn-Sorensen

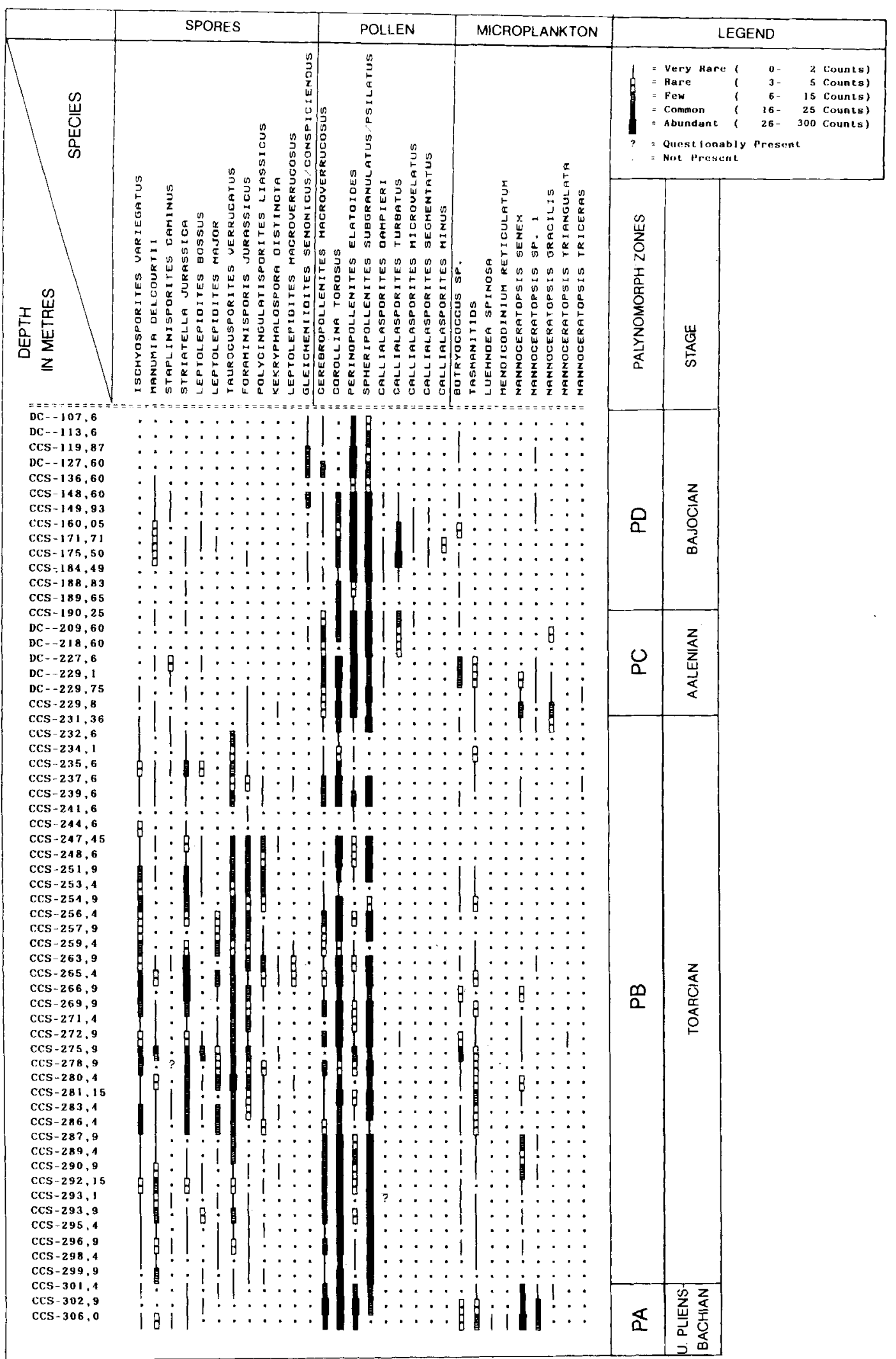

Fig. 3. The distribution of selected palynomorphs in the Jurassic part of the Anholt boring. (DC= ditch cutting sample, CCS= conventional core sample). 


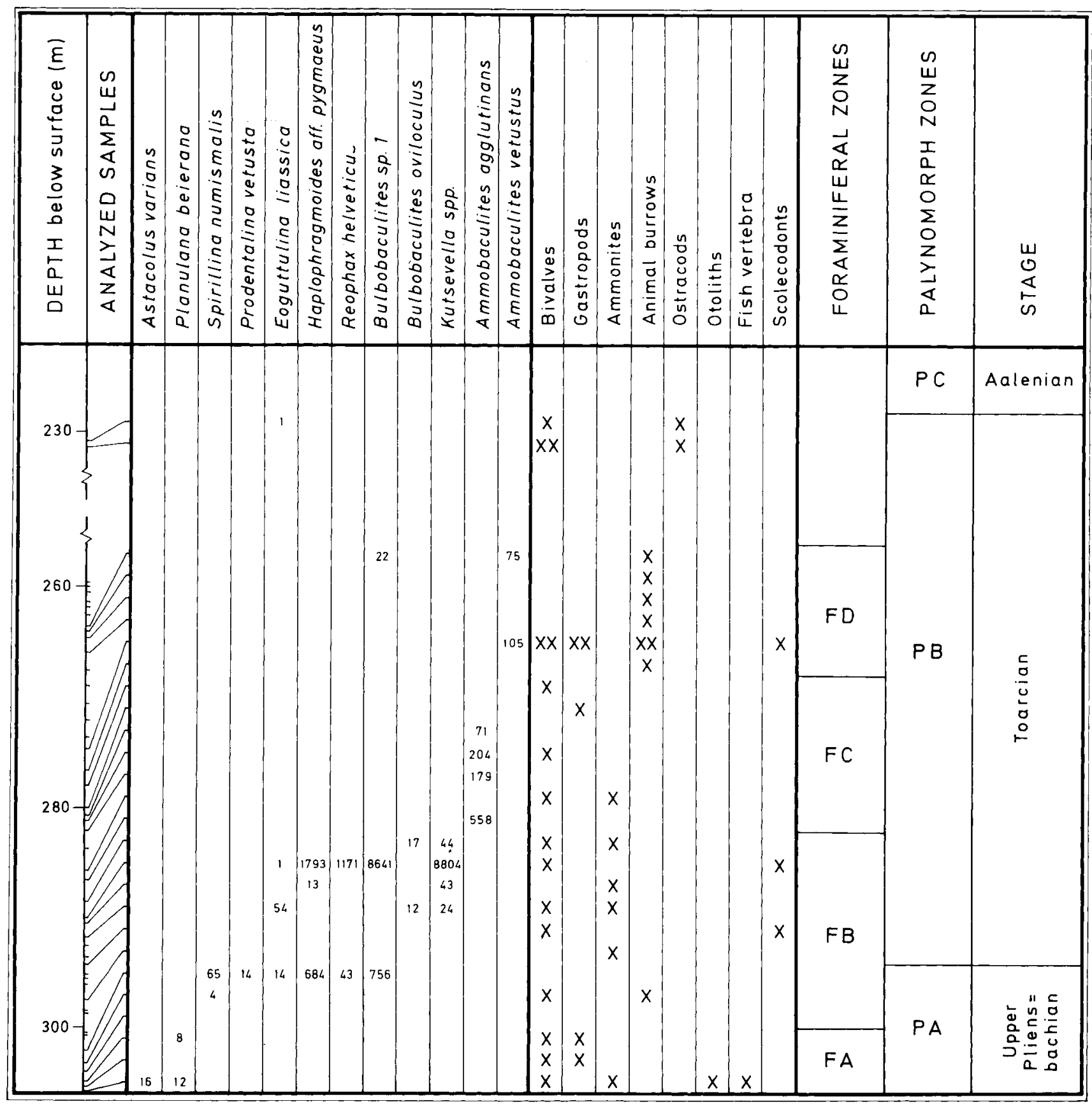

Fig. 4. The distribution of foraminifera and other fossil groups in the Jurassic interval of the Anholt boring. The selected foraminiferal species are given as an estimated number of specimens in $1000 \mathrm{~g}$ sediment. For other species groups: $x=$ present, $x x=$ frequent. All samples are from cores. Barren samples are marked with a short line in the column headed "Analysed samples".

macroverrucosus, Manumia delcourtii (Pl. 2, fig. 8), and Kekryphalospora distincta (P1. 2, fig. 1). Unlike Zone PA, dinoflagellate cysts occur sporadically. The upper part of the zone is characterized by the presence of several megaspores, e.g. Aneuletes patera, Erlansonisporites sp., Striatriletes excavatus, Hughesisporites variabilis, Paxillitriletes reticulatus, and Striatriletes sulcatus spp. (Pl. 4, figs 1-6). The upper part of the zone is characterized by reworked Carboniferous and Triassic spores.

The Perinopollenites elatoides Acme Zone (PC) comprises an assemblage of uniform composition. It is dominated by Perinopollenites elatoides (P1. 3, fig. 1), "replacing" the dominance of Spheripollenites subgranulatus in the underlying Zone PB (Fig. 3). The lower boundary of the 


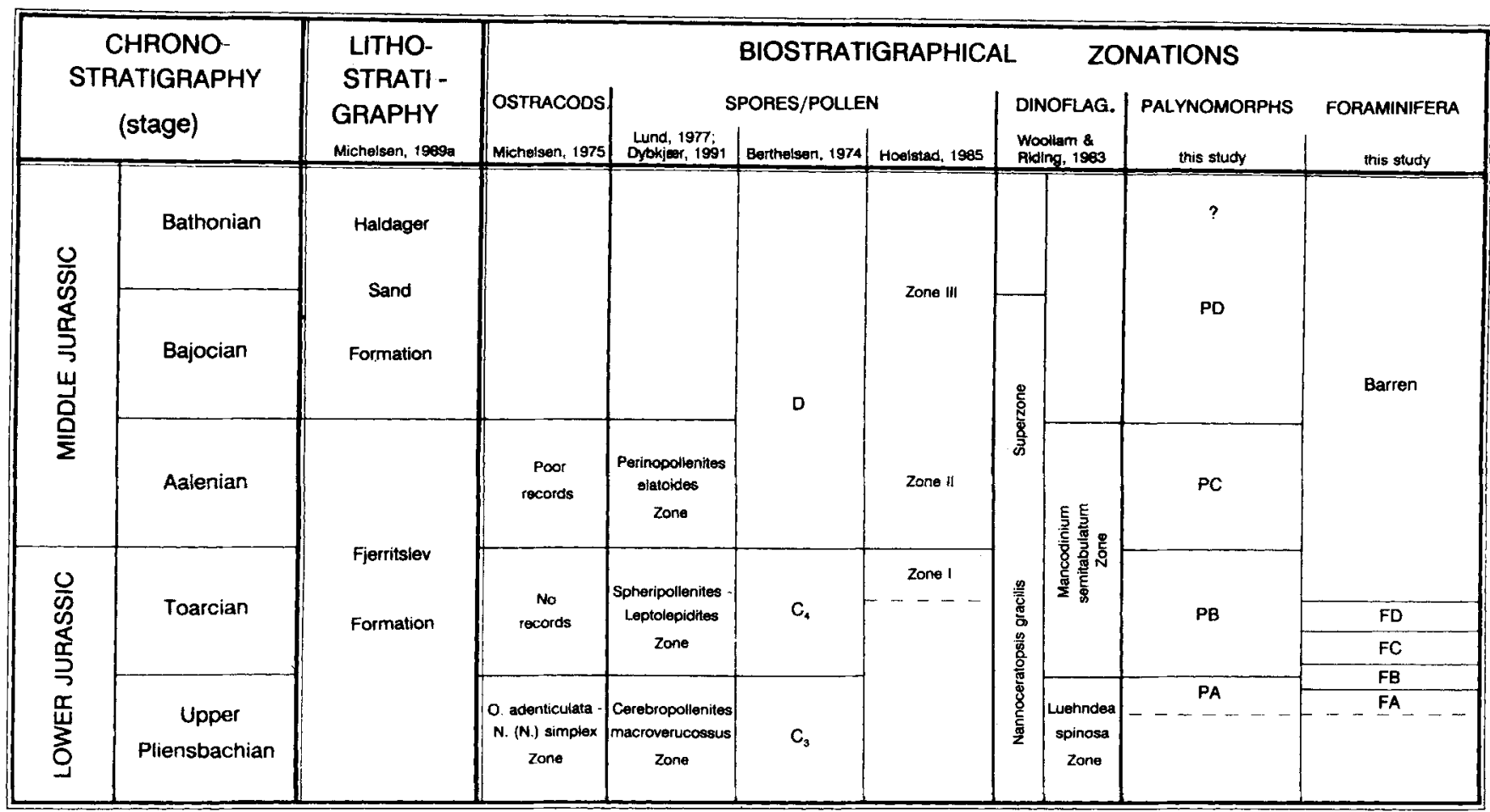

Fig. 5. Lower and Middle Jurassic chrono- and lithostratigraphy of the Norwegian-Danish Basin, selected palynomorph- and ostracod zonations from previous studies in the region, and the local palynomorph and foraminiferal zonation of the Anholt borehole succession.

zone is defined by the marked increase of this species (at $231.4 \mathrm{~m}$ ). Corollina torosus occurs frequently, and a few specimens of Callialasporites turbatus (Pl. 3, fig. 7) and Nannoceratopsis gracilis (PI. 1, fig. 4) are recorded together with reworked Carboniferous and Triassic palynomorphs.

The Callialasporites turbatus - Callialasporites dampieri Assemblage Zone (PD) is also dominated by Perinopollenites elatoides, but it is further characterized by the presence of numerous Callialasporites turbatus and C. dampieri. Other significant palynomorph species are Callialasporites microvelatus (Pl. 3, figs 4 \& 6), C. minus (Pl. 3, fig. 5), Densosporites scanicus (Pl. 2, fig. 11), Neoraistrickia gristhorpensis, Sestrosporites pseudoalveolatus, Gleicheniidites conspiciendus, and G. senonicus, and specimens of Botryococcus have been found sporadically throughout (Fig.
3). The assemblages from the lower half of the zone contain occasional acritarchs, which disappear in the upper part. The palynoflora of the uppermost few metres, which represents the youngest Jurassic sediments in the boring, is characterized by a low diversity and low density assemblage. Reworked Ordovician, Silurian, Devonian, and Triassic palynomorphs occur sporadically throughout.

\section{Foraminiferal zonation}

Fifteen foraminiferal species were identified in the samples examined (Fig. 4). These are concentrated in the interval 306 $\mathrm{m}$ to $231 \mathrm{~m}$. This interval is divided into 4 foraminiferal assemblage zones (sensu Hedberg, 1976). Foraminifera were not recorded from 231-104 $\mathrm{m}$. As for the palynological subdivision, zonal boundaries are placed between two

Microplankton.

\section{Explanation of Plate 1}

Light microscope photographs. Sample depth, slide number, England Finder Reference (EFR), and the Danish Geological Survey (DGU) catalogue number in brackets. Magnification $\times 750$.

Fig. 1. Luehndea spinosa Morgenroth, 1970 (306 m; 1659, D4; EFR M323; DGU-1992-EBK-48). (Photograph kindly given to us by C. Heilmann-Clausen) Fig. 2. Mendicodinium reticulatum Morgenroth, 1970 (306 m; no. 6; EFR K394; DGU-1992-EBK-49) Fig. 3. Nannoceratopsis senex van Helden, 1977 (306 m; no. 6; EFR Z441; DGU-1992-EBK-50) Fig. $4 . \quad$ Nannoceratopsis gracilis Alberti emend. van Helden, 1977 (306 m; no. 6; EFR O244; DGU-1992-EBK-51) Fig. 5. Nannoceratopsis ridingii Poulsen, 1992 (306 m; no. 6; EFR N613; DGU-1992-EBK-52) Fig. 6. Nannoceratopsis triangulata Prauss, 1987 (296,9 m; no. 3; EFR F330; DGU-1992-EBK-53) Fig. 7. Nannoceratopsis triceras Drugg, 1978 (306 m; no. 6; EFR D583; DGU-1992-EBK-54) Fig. 8. Crassosphaera sp. (306 m; no. 6; EFR P304; DGU-1992-EBK-55) 


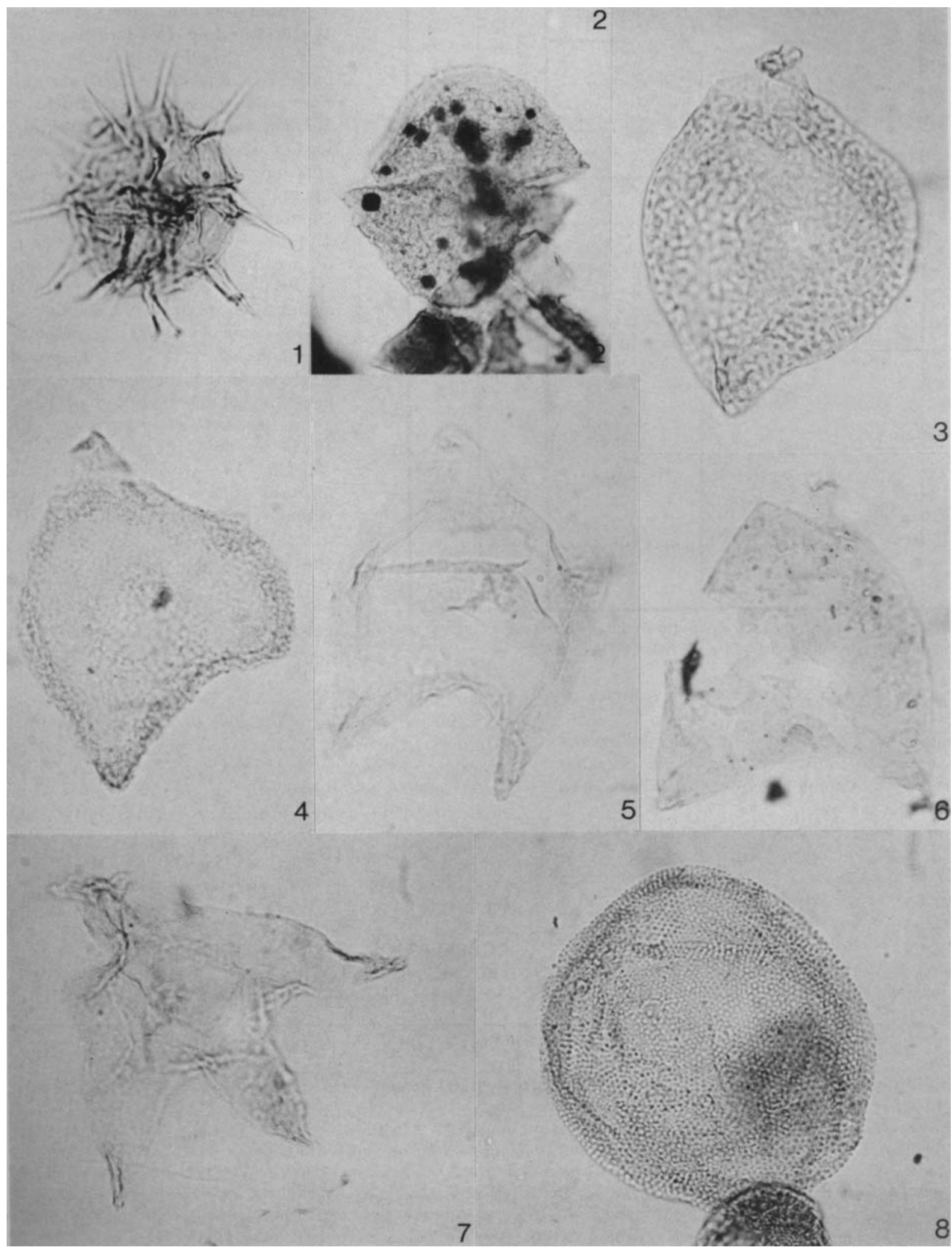




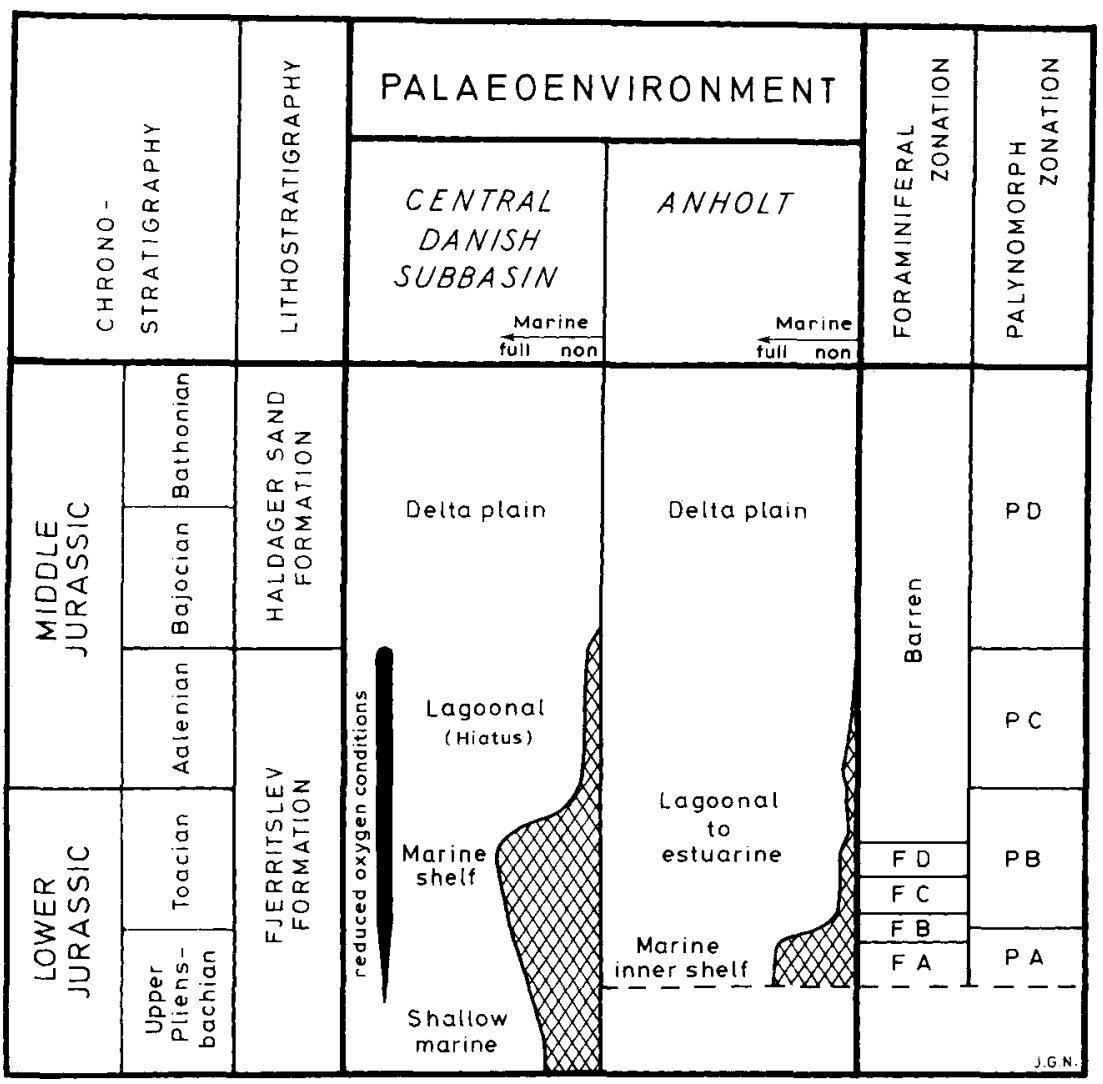

Fig. 6. Comparison of the interpreted palaeoenvironment with the palaeoenvironment of the central Danish Subbasin, as described by Michelsen (1978, 1989b).

sampling horizons (Fig. 4). The locations of the samples are shown on Fig. 4.

All foraminiferal tests are filled with pyrite and several calcareous specimens are preserved only as pyrite casts. It is possible, therefore, that some specimens may have been destroyed during diagenesis.

The lowermost Astacolus varians - Planularia beierana Assemblage Zone (FA) contains only the Nodosaridae Astacolus varians and Planularia beierana (Fig. 4). Other fossil groups recorded were gastropods, bivalves, and ammonites.

The overlying Haplophragmoides aff. pygmaeus Bulbobaculites sp. 1 Assemblage Zone (FB) represents the most diverse Jurassic foraminiferal fauna in the boring and includes 8 species (Fig. 4). The assemblage is characterized by the agglutinated species Bulbobaculites oviculus, Haplophragmoides aff. pygmaeus, Reophax helveticus, and Kutsevella spp. Several specimens of Spirillina numismalis are present in the lower part of the zone, while Kutsevella spp. have only been recorded in the upper part. Other fossil groups include ammonites, bivalves and scolecodonts. The lower boundary of this zone is defined by the disappearance of the Nodosaridae and the appearance of agglutinated species at about $304 \mathrm{~m}$.

The Ammobaculites agglutinans Assemblage Zone (FC) contains almost solely the nominate arenaceous species in relatively high numbers (Fig. 4). Just a few specimens of Ammobaculites aff. alaskaensis and one speciemen of a Trochammina were found in the uppermost two samples. The lower boundary of the zone is defined at the disappearance of the species characterizing Zone FB and the appearance of Ammobaculites agglutinans (at $287 \mathrm{~m}$ ). Bivalves and gastropods are occasionally present in small numbers.

The Ammobaculites vetustus Assemblage Zone (FD) is characterized by the sporadic occurrence of $A$. vetustus and Bulbobaculites sp. 1. Animal burrows filled with pyrite are common. The lower boundary of this zone is defined at the disappearance of Ammobaculites agglutinans and the first occurrence of $A$. vestustus. The upper boundary is defined at the disappearance of foraminifera at $264 \mathrm{~m}$.

The interval above Zone FD is barren of foraminifera except for a single specimen of Eoguttulina liassica at $231 \mathrm{~m}$ below core top.

\section{CORRELATION AND STRATIGRAPHY}

The chronostratigraphy of the Anholt section is based entirely on the palynomorphs because the foraminiferal

\section{Spores and pollen.}

\section{Explanation of Plate 2}

Light microscope photographs. Sample depth, slide number, England Finder Reference (EFR), and the DGU catalogue number in brackets. Magnification x 750 .

Fig. 1. Kekryphalospora distincta Fenton \& Riding, 1987 (283,4 m; no. 3; EFR Z284; DGU-1992-EBK-56) Fig. $2 . \quad$ Taurocusporites verrncatus Schulz, 1967 (237,6 m; no. 3; EFR N514; DGU-1992-EBK-57) Fig. 3. Polycingulatisporites liassicus Schulz, 1967 (239,6 m; no. 3; EFR B360; DGU-1992-EBK-58) Fig. 4. Foraminisporis jurassicus Schulz, 1967 (237,6 m; no. 3; EFR N514; DGU-1992-EBK-59) Fig. 5. Leptolepidites major Couper, 1958 (248,6 m; no. 2; EFR Z513; DGU-1992-EBK-60) Fig. 6. Leptolepidites bossus (Couper) Schulz, 1967 (237,6 m; no. 3; EFR P602; DGU-1992-EBK-61) Fig. 7. Uvaesporites argenteaeformis (Bolkhovitina) Schulz, 1967 (263,9 m; no. 3; EFR J361; DGU-1992-EBK-62) Fig. 8. Manumia delcourtii (Pocock) Dybkjaer, 1991 (306 m; no. 6; EFR R600; DGU-1992-EBK-63) Fig. 9. Ischyosporites variegatus (Couper) Schulz, 1967 (265,4 m; no. 3; EFR D490; DGU-1992-EBK-64) Fig. 10. Spheripollenites subgranulatus Couper, 1958 (239,6 m; no. 3; EFR B360; DGU-1992-EBK-65) Fig. 11. Densoisporites scanicus Tralau, 1968 Fig. 12, 13. Spheripollenites psilatus Couper, 1958 (239,6 m; no. 3; EFR B360; DGU-1992-EBK-66) 


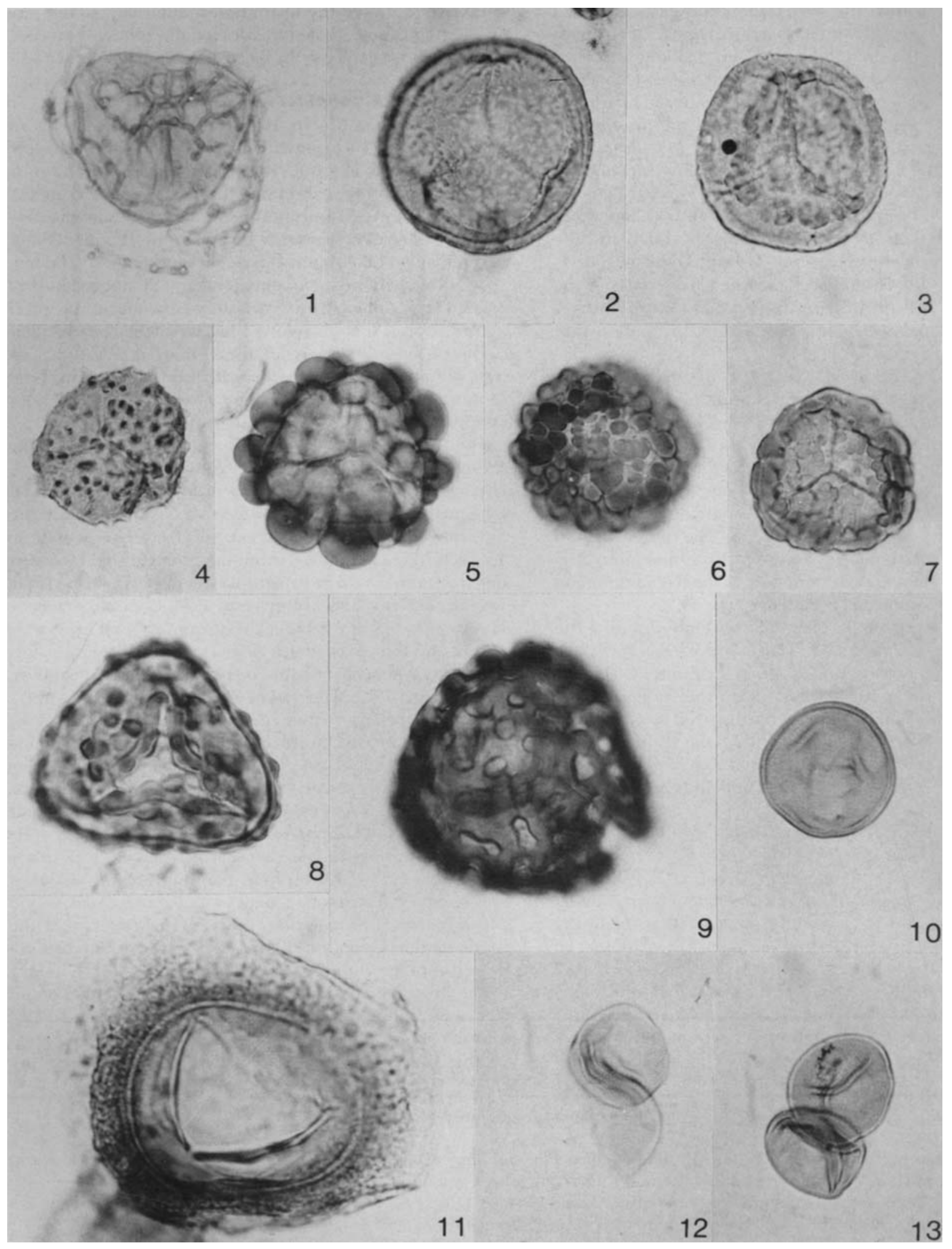


assemblages cannot be correlated with faunas from other localities in this area. The stratigraphic correlation is based on comparisons with palynostratigraphic studies of deposits where the stratigraphical determinations are based on ammonites, ostracod, or dinoflagellate cyst assemblages.

On the basis of the abundant occurrence of the dinoflagellate genus Nannoceratopsis and the presence of rare specimens of Luehndea spinosa and Mendicodinium reticulatum, Zone PA is correlated with the English Luehndea spinosa Zone of Woollam and Riding (1983), with Zone C3 (in the Hobro-1 boring) of Bertelsen (1974), with the top of Zone C (in Gassum-1 boring) of Dybkjaer (1988) and the Cerebropollenites macroverrucosus Zone of Dybkjaer (1991) (Fig. 5), and with assemblages recorded from parts of the Bagå Formation on Bornholm (Fig. 1) (Koppelhus \& Nielsen, in prep.). These correlations indicate a late Pliensbachian age

The abundance of Spheripollenites and Corollina, and the presence of Ischyosporites variegatus and Manumia delcourtii indicate a Toarcian age for Zone PB. The palynomorph assemblage allows a correlation with Zone C4 (Hobro-1 boring) of Bertelsen (1974), with the SpheripollenitesLeptolepidites Zone in the Stenlille borings (Dybkjaer, 1991), and with Zone I in the Hasle Klinkerfabrik clay Pit, Bornholm, of Hoelstad (1985) (Figs 1,5). The composition of the megaspore assemblages recorded from this interval is comparable to that known from part of the Baga Formation on Bornholm (Koppelhus \& Batten, 1992).

The dominance of Perinopollenites elatoides and the sporadic occurrence of Callialasporites turbatus, Nannoceratopsis gracilis, and N. senex in Zone PC (Fig. 4) suggest a correlation of that zone with the Perinopollenites elatoides Zone, which has been allocated a presumed Aalenian age (Dybkjaer, 1991), with Zone II of Hoelstad (1985), and with assemblages recorded in other parts of the Bagå Formation from Bornholm (Koppelhus \& Nielsen, in prep.) (Figs 1,5).

The dominance of Perinopollenites elatoides and the presence of Callialasporites turbatus, C. dampieri, $C$. microvelatus, C. minus, Densosporites scanicus, Neoraistrickia gristhorphensis, Sestrosporites pseudoalveolatus, Gleicheniidites conspiciendus, and G. senonicus indicate that Zone PD correlates with the Middle Jurassic Zone D in Hobro-1 of Bertelsen (1974) and with Zone III (Hasle Klinkerfabrik clay pit) of Hoelstad (1985) (Fig. 5). The lack of dinoflagellate cysts and other stratigraphically significant fossil groups hampers certain chronostratigraphical determination of this zone (and those beneath) zones. The spore/pollen stratigraphy of the Middle Jurassic in the area is not well established. Since the examined assemblages lack any species indicating a Late Jurassic age, the zone is, however, suggested to encompass the Bajocian to Bathonian interval.

\section{PALAEOENVIRONMENTAL CONDITIONS}

The dominance of Nodosaridae (foraminifera) and dinoflagellate cysts together with a low TOC content (below $1 \%$ ) suggest a marine shelf environment with welloxygenated bottom conditions for foraminiferal Zone FA (the lower part of palynomorph Zone PA) in the late Pliensbachian. The presence of ammonite fragments and fish remains also support this suggestion (Fig. 4). The low species diversity in the foraminiferal and dinoflagellate cyst assemblages does, however, suggest a more marginal marine aspect. It is, therefore, suggested that Zone FA was deposited under marine inner shelf conditions, an interpretation which accords with Jurassic foraminiferal facies trends documented by Gordon (1970), Nagy (1985a,b), Copestake (1989), and Nagy et al. (1990).

The low species diversity and the dominance of the arenaceous foraminiferal genera Bulbobaculites, Haplophragmoides, and Kutsevella in foraminiferal Zone FB (the upper part of palynomorph Zone PA and the lowermost part of PB), combined with the presence of 0.5 to $1 \%$ TOC (Fig. 2), implies a well-oxygenated, shallow water environment with reduced salinities (Johnson, 1976; Løfaldli \& Nagy, 1980; Nagy et al., 1984; Copestake, 1989; J. Nagy, pers. comm. 1992). The foraminifera Eoguttulina liassica and the scolecodonts (Fig. 4) also indicate a shallow water environment, possibly of reduced salinity (Brouwer, 1969; Kozur, 1972; Copestake, 1989; Courtinat et al., 1991). Furthermore, the upwards-decreasing frequency of dinoflagellate cysts and increasing amounts of spores and pollen (Fig. 3) suggest a gradual decrease in distance from the shoreline through the interval. Hence, this zone represents a regression from marine inner shelf environments of Zone FA to near lagoonal or deltaic conditions during the late Pliensbachian and early Toarcian. The presence of ammonite fragments and isolated specimens of the dinoflagellate cysts Luehndea spinosa and Mendicodinium reticulatum, indicate, however, that the marine influence on the environment of deposition had not ceased entirely.

The low diversity faunas of agglutinated foraminifera in Zones FC and FD (middle part of palynomorph Zone PB), and the sparse dinoflagellate cysts, indicate a continuation of this inshore trend to a fully lagoonal to estuarine

\section{Explanation of Plate 3}

\section{Pollen.}

Light microscope photographs. Sample depth, slide number, England Finder Reference (EFR), and the DGU catalogue number in brackets. Magnification $\times 750$, except for figs 4,5,6 and 7 which are $\times 1000$, and fig. 8 which is $\times 560$.

Fig. 1. Perinopollenites elatoides Couper, 1958 (229,8 m; no. 3; EFR E584; DGU-1992-EBK-67) Fig. 2. Tetrad of Corollina torosus Traverse, 1975 (306 m; no. 6; EFR W370; DGU-1992-EBK-68) Fig. 3. Quadraeculina anellaeformis Malyavkina, 1949 (306 m; no. 6; EFR W370; DGU-1992-EBK-69) Fig. 4. Callialasporites microvelatus Schulz, 1966 (184 m; EFR S254) Fig. 5. Callialasporites minus (Tralau) Guy, 1971 (160 m; EFR L181) Fig. 6. Callialasporites microvelatus Schulz, 1966 (151 m; EFR H240) Fig. 7. Callialasporites turbatus (Balme) Srivastava, 1963 (175 m; EFR L184) Fig. 8. Campenia gigas Mädler, 1963 (306 m; no. 6; EFR Y420; DGU-1992-EBK-70) 


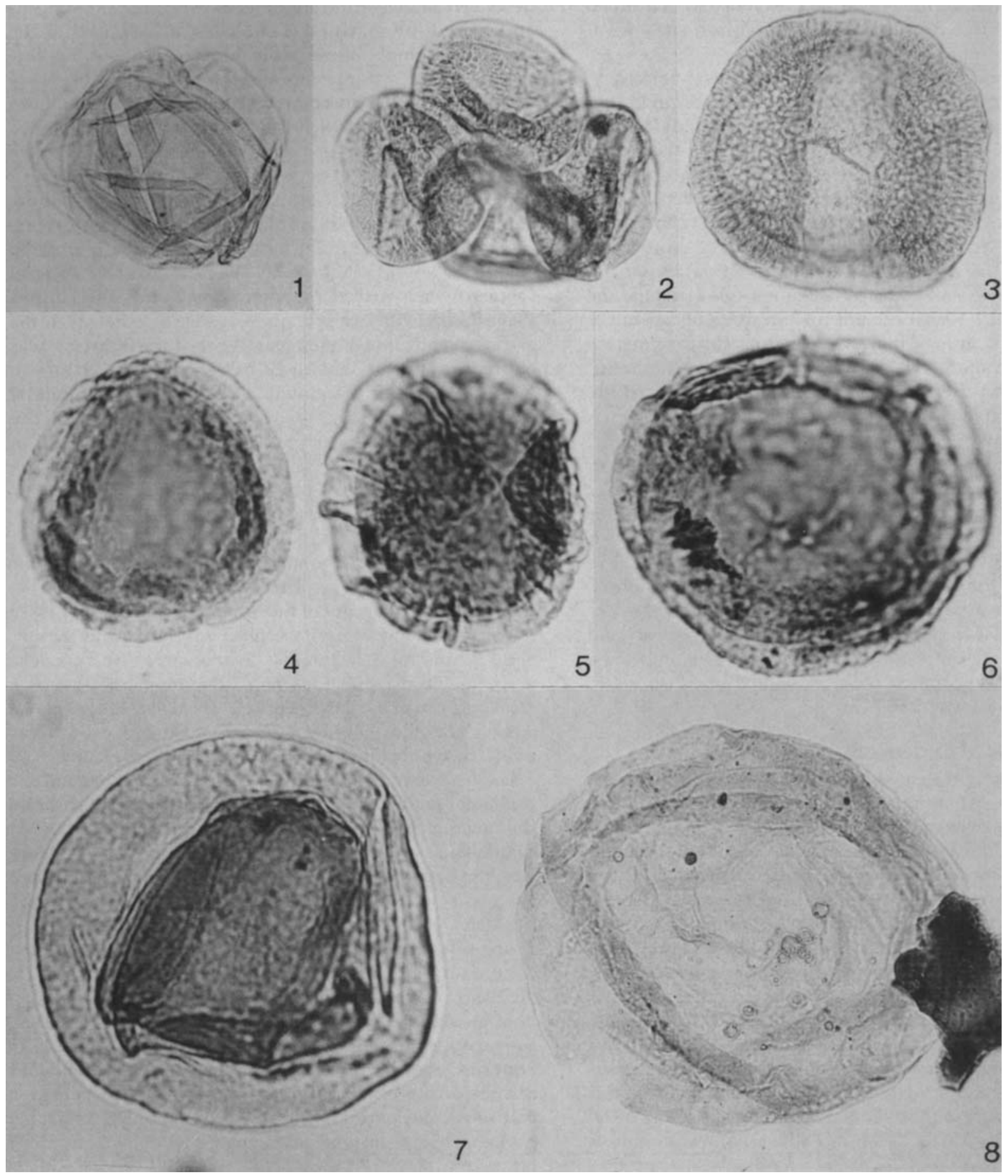


environment. The general decrease in the foraminiferal and marine palynomorph content is a response to continued regression. An average of $0.5 \%$ TOC indicates welloxygenated conditions.

The presence of the planktonic algal genus Botryococcus, which is normally considered to be a freshwater indicator, but which may be tolerant of slightly brackish water (Traverse \& Ginsburg, 1966; Tappan, 1980), and the lack of foraminifera (Figs 3,4) in the upper part of the palynomorph Zone $\mathrm{PB}$, indicate further regression leading to an inner deltaic or estuarine and non-marine conditions.

The presence of dinoflagellate cysts, especially Nannoceratopsis gracilis, and acritarchs in palynomorph Zone PC (Fig. 3) and the presence of a single foraminiferal specimen and a few specimens of ostracods and bivalves just below $230 \mathrm{~m}$ may indicate a brief brackish or marine influx into a mainly lagoonal or deltaic environment. Nannoceratopsis gracilis may have been tolerant of brackish, but not of freshwater environments (Hancock \& Fisher, 1981; Riding, 1983). Although acritarchs are mainly marine they may occur relatively abundantly in shallow bays and lagoons in association with low diversity assemblages of dinoflagellate cysts, and sometimes even in freshwater environments (Erkmen \& Sarjeant, 1980; Hancock \& Fisher, 1981; Batten, 1982).

In the uppermost part of the Jurassic section at Anholt, Zone PD, the foraminifera and dinoflagellate cysts are lacking and acritrachs only present in the lower part and Botryococcus present throughout the zone. This indicate a delta plain environment with occasional brackish water influence in the lower part.

\section{DISCUSSION AND CONCLUSIONS}

The palynomorph assemblages from the Jurassic of the Anholt boring are similar to those described from other sites in the Norwegian-Danish Basin and on Bornholm (Fig. 5). This facilitates a close correlation of the Anholt section to other sections within the region. Similar assemblages have also been described, for example, from Germany (Schulz, 1967), Britain (Woollam \& Riding, 1983; Riding et al. 1991), and East Greenland (Lund \& Pedersen, 1985), suggesting a rather uniform flora over a large part of north-west Europe and Greenland during the Early - Mid Jurassic. This coincides with the relatively rather uniform climatic regime in the area during that time (Hallam, 1984).

Lower Jurassic foraminiferal faunas have been described from several localities within the Norwegian-Danish Basin and adjacent areas (Nørvang, 1957; Bang, 1968 a,b, 1971, 1973; Norling, 1970, 1972), but those from the Anholt succession are markedly dissimilar. These previously described faunas are from older Lower Jurassic deposits and from fully marine assemblages, as opposed to the mainly marginal marine associations at Anholt. Shallow water foraminiferal faunas comparable to those encountered in the Toarcian of Anholt have, however, been encountered previously in the Lower Jurassic Wilhelmøya Formation of Spitsbergen (J. Nagy, pers. comm. 1992).

A comparison of the sedimentological and palaeontological data from the Anholt section with those from previous investigations in the region indicates a discrepancy in the timing of the onset of the regression during the latest Early Jurassic. The main phase of sea level lowering at Anholt occurred around the upper Pliensbachian/Toarcian boundary (Fig. 6), whereas in the centre of the Danish Subbasin most of the Toarcian was characterized by an increase in marine influence corresponding to the global sea level rise described by Hallam (1988). This sea level rise resulted in the establishment of stagnant bottom conditions in the centre of the basin (Michelsen, 1989b), and shallowing of the water apparently did not take place here until the late Toarcian, when a lagoonal environment was established (Michelsen, $1989 \mathrm{a}, \mathrm{b})$.

The regression at Anholt whichoccurredas early as the latest Pliensbachian, and thus slightly earlier than the shallowing in the centre of the basin, may have been caused by the prograding of the delta plain which characterized the basin during the Mid Jurassic (Michelsen, 1978). This delta progradation may have reached the more marginal Anholt area earlier than the basin centre. The Toarcian regression at Anholt may, however, also be the result of local tectonic uplift triggered within the Fennoscandian Border Zone.

The boundary between the Fjerritslev Formation and the Haldager Sand Formation in the Norwegian-Danish Basin has previously been considered coincident with the LowerMiddle Jurassic boundary (Michelsen 1978, 1989a). More recently, though, Michelsen \& Nielsen (1991) have indicated the possibility of an Aalenian age for the upper part of the Fjerritslev Formation in the Terne-1 boring (Fig.1). But they chose to place the Lower/Middle Jurassic boundary between the Fjerritslev and Haldager Sand formations on the basis of lithostratigraphy. The biostratigraphical data from the Anholt boring, however, presents new information concerning the age of this formational boundary. The boundary between the Fjerritslev and Haldager Sand formations corresponds to the boundary between palynomorph Zones PC and PD in the boring (Fig. 5) (see Nielsen, 1992). Since the palynomorph assemblage of Zone

\section{Explanation of Plate 4}

\section{Megaspores.}

Scanning electron micrographs. Sample depth, stub number, and catalogue the DGU number in brackets. Magnification $x 150$.

Fig. 1. Aneuletes patera Harris, 1961 (240.49-.52 m; stub 1.1; DGU-1992-EBK-71) Fig. 2. Erlansonisporites sp. (240.49-.52 m; stub 1.2; DGU-1992-EBK-72) Fig. 3. Striatriletes excavatus (Marcinkiewicz) Sweet, 1979 (240.49-.52 m; stub 1.3; DGU-1992-EBK-73) Fig. 4. Hughesisporites variabilis Dettmann, 1961 (240.49-.52 m; stub 1.4; DGU-1992-EBK-74) Fig. 5. Paxillitriletes reticulatus (Mädler) Hall \& Nicolson, 1973 (236.69-.72 m; stub 1.6; DGU-1992-EBK-75) Fig. 6. Striatriletes sulcatus (Dijkstra) Potonié, 1956 (240.12-.15 m; stub 1.7; DGU-1992-EBK-76) 

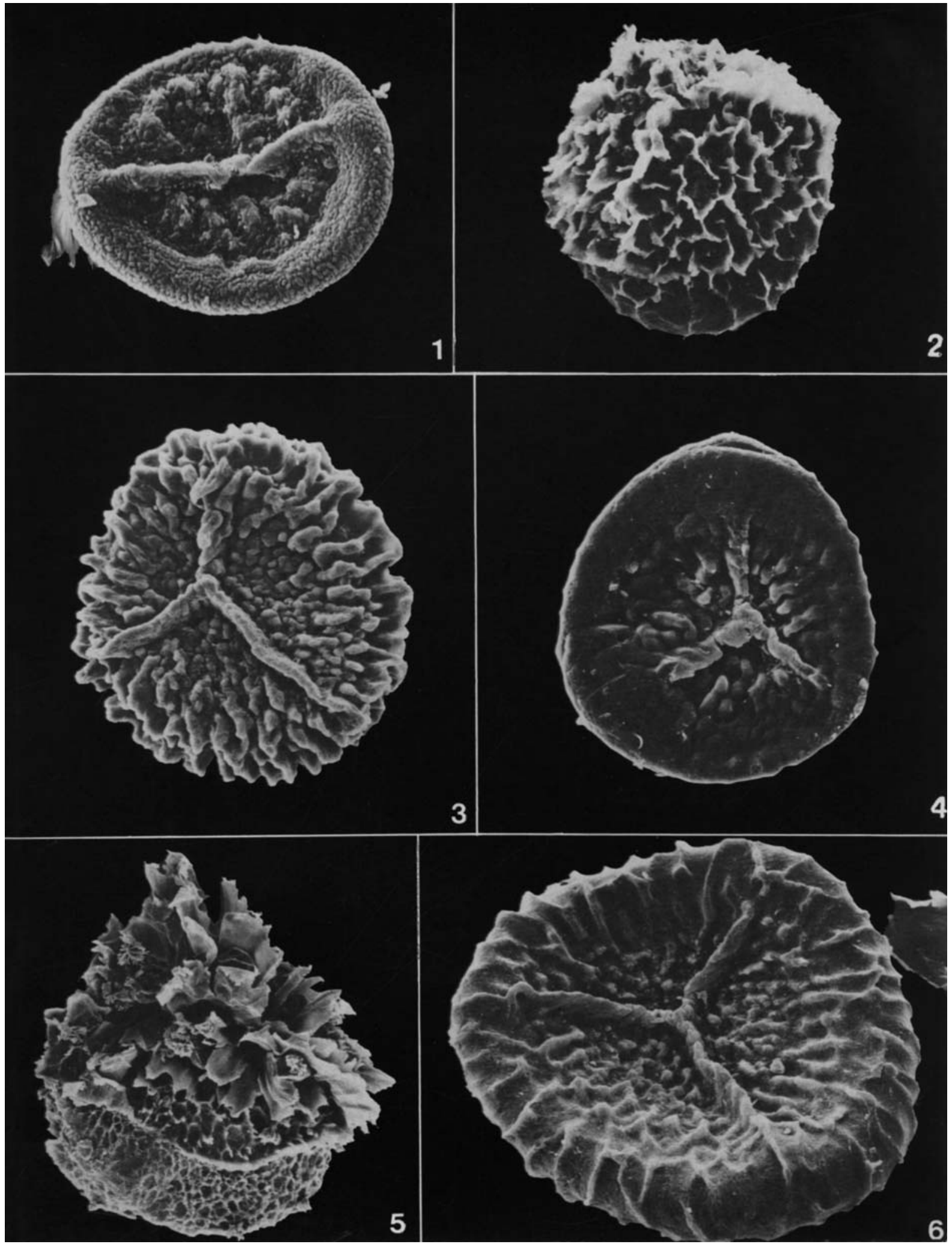
PC indicates an Aalenian age, the uppermost part of the Fjerritslev Formation at Anholt can be dated as Mid Jurassic.

\section{ACKNOWLEDGEMENTS}

We are grateful to David J. Batten (University College of Wales), Karen Luise Knudsen (University of Aarhus (AU)), Olaf Michelsen (AU), Jenö Nagy (University of Oslo), Lars Henrik Nielsen (Geological Survey of Denmark), Kaj Raunsgaard Pedersen (AU), and David N. Penney (AU) for valuable discussions and critically reading the manuscript. We also thank an unnamed referee for valuable comments. Our sincere thanks also to Jenö Nagy for help with determination of the foraminiferal species, to John $D$. Taylor and Phillip Palmer (The Natural History Museum, London) for examining the Gastropoda, and to Ole Bjørslev Nielsen and Birthe Schmidt (AU) who let us use unpublished data. We are grateful to Jette Gissel Nielsen (AU), who processed the foraminiferal samples and prepared the drawings, to Bitten Larsen (AU) and Yvonne Husfledt (DGU) for processing the palynological samples, to Svend Meldgaard Christensen (AU) for the foraminiferal photographs, and to Peter Moors (DGU) for developing and printing the palynomorph photographs. The work was supported by the Danish Natural Science Research Council and the Carlsberg Foundation.

\section{REFERENCES}

Bang, 1. 1968. Biostratigraphical investigation of the preQuaternary in the Øresund boreholes mainly on the basis of foraminifera. In Larsen, G. et al. (1968), Øresund. HelsingørHälsingborg Linien. Geologisk Rapport. Danmarks geologiske Undersøgelse, Rapport 1, Copenhagen, 90 pp, 24 pls.

Bang, I. 1971. Jura aflejringerne i Ronde nr. 1 (2103-2614 m), biostratigrafi på grundlag af foraminiferer. In Rasmussen, $\mathrm{L}$. B. (Ed.), Dybdeboringen Rønde nr. 1 på Djursland. Danmarks geologiske Undersogelse, Rk. III, Copenhagen, 39, 74-80.

Bang, I. 1973. Jura-biostratigrafi i Nøvling nr. 1 på grundlag af Foraminiferer. In Rasmussen, L. B. (Ed.), Dybdeboringen Nøvling nr. 1 i Midtjylland. Danmarks geologiske Undersegelse, Rk. III, Copenhagen, 40, 191-123. (English summary).

Batten, D.J. 1982. Palynofacies and salinity in the Purbeck and Wealden of southern England.In Aspects of Micropalaeontology (Banner, F.T. \& Lord, A.R. eds), George Allen \& Unwin, London, 278-308.

Bertelsen, F. 1974. Palynological investigations of the TriassicJurassic section of the Hobro No. 1 borehole. In Michelsen; O., 1979, Report on the Jurassic of the Hobro No. 1 and Voldum No. 1 borings, Denmark. Danmarks geologiske
Undersagelse, Arbog 1978, Copenhagen, 141-149.

Brouwer, J. 1969. Foraminiferal assemblages from the Lias of North-Western Europe. Verhandelingen der Koninklijke Nederlandse Akademie van Wetenschappen,. Afd. Natuurkunde, 1 reeks, Amsterdam, 25 (4), 1-65.

Copestake, P. 1989. Jurassic. In Jenkins, D. G. \& Murray, J. W. (Eds.), Stratigraphical atlas of fossil foraminifera, 123-272. British Micropalaeontological Society Series, Ellis Horwood Ltd., Chichester.

Courtinat, B., Atrops, F. \& Ferry, S. 1991. Les scolécodontes du Jurassique moyen et du Crétacé du sud-est de la France. Revue de Micropaleontology, Paris, 34, 95-104.

Dybkjaer, K. 1988. Palynological zonation and stratigraphy of the Jurassic section in the Gassum No. 1-borehole, Denmark. Danmarks geologiske Undersogelse, Serie A, Copenhagen, 21, 173.

Dybkjaer, K. 1991. Palynological zonation and palynofacies investigation of the Lower to lowermost Middle Jurassic Fjerritslev Formation in the Danish Subbasin. Danmarks geologiske Undersogelse, Serie A, Copenhagen, 30, 1-150.

Erkmen, U. \& Sarjeant, W.A.S., 1980. Dinoflagellate cysts, acritarchs and tasmanitids from the uppermost Callovian of England and Scotland: with a reconsideration of the "Xanthidium pilosum" problem. Geobios, Lyon, 13, 45-99.

Gordon, W. A. 1970. Biogeography of Jurassic Foraminifera. Bulletin of the Geological Society of America, Colorado, 81, 16891704.

Hallam, A. 1984. Continental humid and arid zones during the Jurassic and Cretaceous. Palaeogeography, Palaeoclimatology, Palaeoecology, Amsterdam, 47, 195-223.

Hallam, A. 1988. A reevaluation of Jurassic eustasy in the light of new data and the revised Exxon Curve. In Wilgus, C.K. et al. (Eds.), Sea-level changes: an integrated approach. Society of Economic Paleontologists and Mineralogists Special Publication, Tulsa, Oklahoma, 42, 261-273.

Hancock, N.J. \& Fisher, M.J., 1981. Middle Jurassic North Sea deltas with particular reference to Yorkshire. Petroleum Geology of the Continental Shelf of N.W. Europe, 186-195.

Hedberg, H. H. 1976. International stratigraphical guide. A guide to stratigraphic classification, terminology and procedure, Wiley and Sons, New York, 200 pp.

Hoelstad, T. 1985. Palynology of the uppermost Lower to Middle Jurassic strata on Bornholm, Denmark. Bulletin of the geological Society of Denmark, Copenhagen, 34, 111-132.

Johnson, B. 1976. Ecological ranges of selected Toarcian and Domerian (Jurassic) foraminiferal species from Wales. 1st. Intenational Symposium on Benthonic Foraminifera of Continental Margins. Pt. B: Palaeoecology and Biostratigraphy. Maritime Sediments, Special Publication 1, Halifax, 545-556.

Foraminifera.

\section{Explanation of Plate 5}

Light microscope photographs. Sample depth in brackets. Magnification $\times 90$. Figs 1, 2. Ammobaculites agglutinans (d'Orbigny, $1846=$ Spirolina agglutinans) $(286.63-.68 \mathrm{~m})$. Figs 3, 4. Haplophragmoides aff. pygmaeus (Haeusler, $1881=$ Rotalia pygmaea) $(302.20-.25 \mathrm{~m})$. Figs 5 , 6. Spirillina numismalis Terquem \& Berthelin, $1875(302.20-.25 \mathrm{~m})$. Fig. 7. Kutsevella sp. 1, (290.08-.12 m). Figs 8, 9. Kutsevella sp. 2 (290.08-12 m). Fig. 10. Ammobaculites aff. alaskensis Tappan, 1955 (281.20-.25 m). Fig. 11. Ammobaculites vetustus (Terquem \& Berthelin, $1875=$ Haplophragmium vetustum) $(274.83-.90 \mathrm{~m})$. Fig. 12. Reophax helvetica $($ Haeusler, $1881=$ Dentalina helvetica) $(302.20-.25$ $\mathrm{m}$ ). Fig. 13. Bulbobaculites oviloculus (Nagy, $1991=$ Bulbobaculites oviloculus) $(288.59-.64 \mathrm{~m})$. Figs 14, 15. Bulbobaculites sp. 1 (302.20-.25 m). Figs 16, 17. Planularia beierana (Gümbel, 1862 = Marginulina beierana) (305.95-306.00 m). Fig. 18. Astacolus varians (Bornemann, $1854=$ Cristellaria varians $)(305.95-306.00 \mathrm{~m})$. Fig. 19. Prodentalina vetusta (d'Orbigny, $1849=$ Dentalina vetusta) $(302.20-.25 \mathrm{~m})$. Fig. 20 . Eoguttulina liassica (Strickland, $1846=$ Polymorphina liassica) $(291.80-.84 \mathrm{~m})$. 

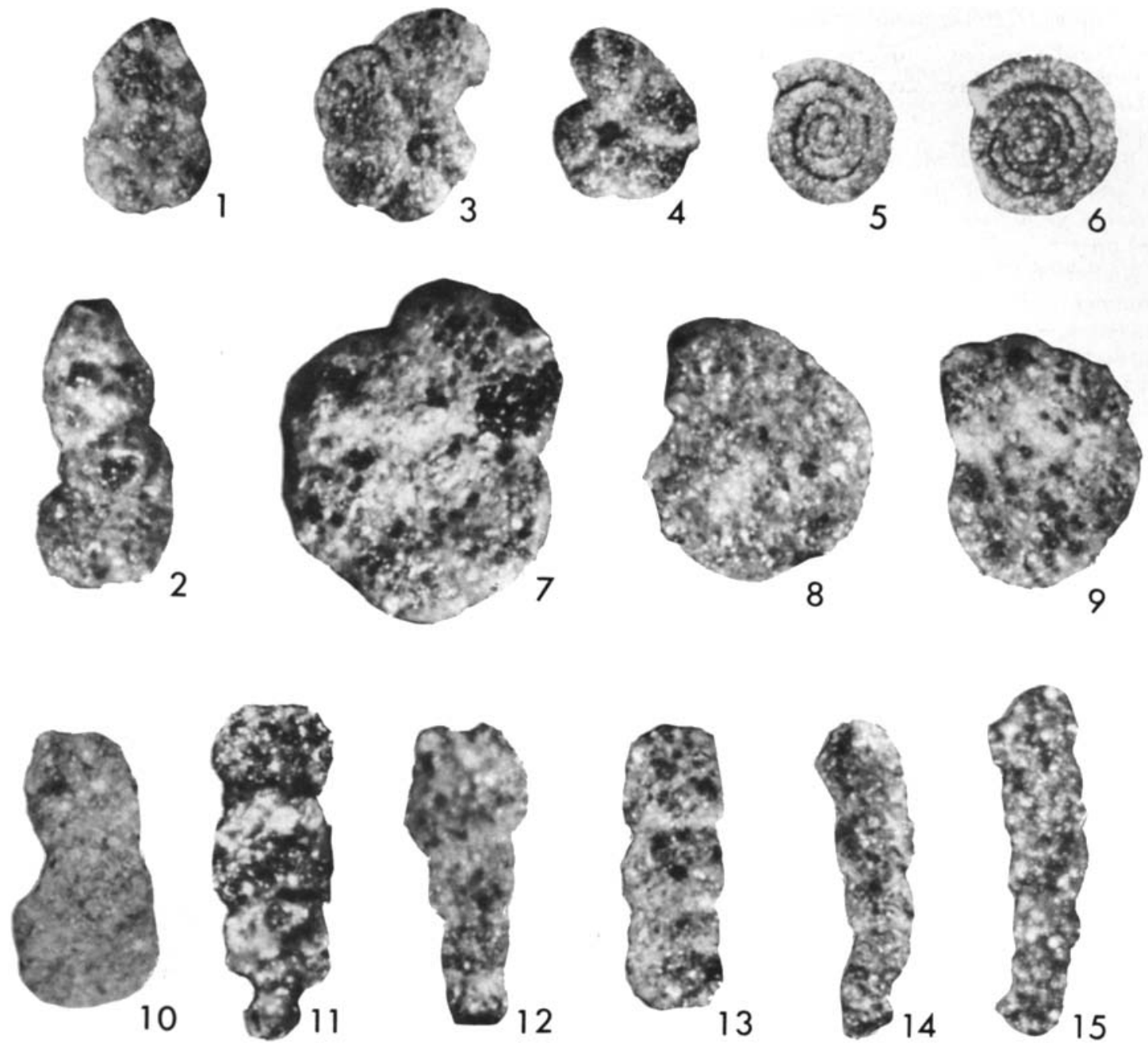

13
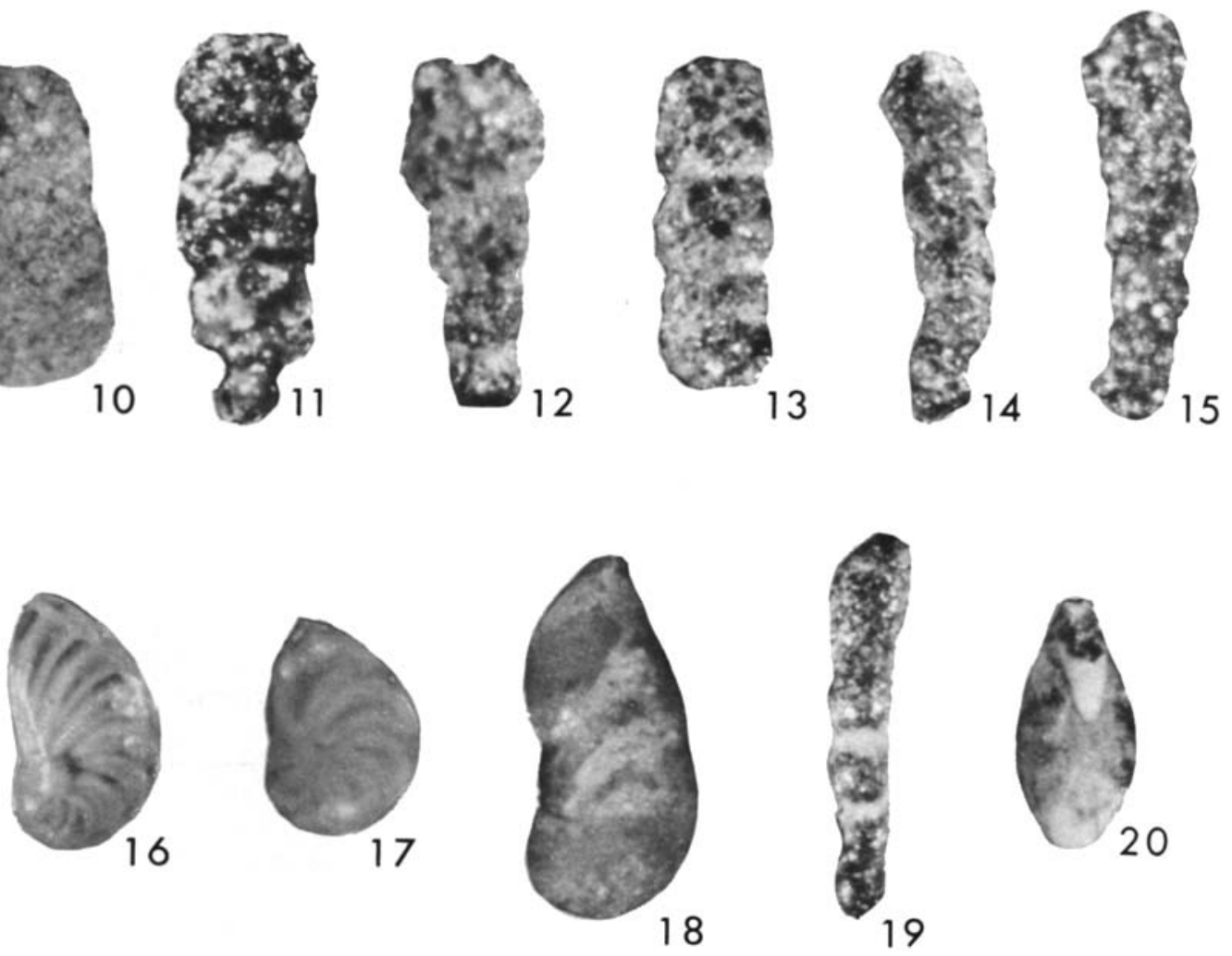
Koch, J.-O. 1983. Sedimentology of Middle and Upper Jurassic sandstone reservoirs of Denmark. Geologie Mijnbouw, Dordrecht, 16, 115-129.

Korsbech, U. \& Gynther Nielsen, K. 1990a. SNG-log i Anholt IV. Unpubl. report, BHR-56, DTH, Department of Elektrophysics, Copenhagen, $16 \mathrm{pp}$.

Korsbech, U., \& Gynther Nielsen, K. 1990b. Supplerende SNG$\log$ i Anholt IV. Unpubl. report, BHR-56, DTH, Department of Elektrophysics, Copenhagen, $11 \mathrm{pp}$.

Koppelhus, E.B. \& Batten, D.J. 1992. Megaspore assemblages from the Jurassic and lowermost Cretaceous of Bornholm, Denmark. Danmarks geologiske Undersogelse, Serie A, Copenhagen 32, $81 \mathrm{pp}$.

Koppelhus E.B. \& Nielsen, L.H. in prep. Palynostratigraphy and palaeoenvironments of the Lower to Middle Jurassic Bagå Formation of Bornholm, Denmark.

Kozur, H. 1972. Die Bedeutung der triassischen Scolecodonten insbesondere für die Taxonomie und Phylogenie der fossilen Eunidica. Mitteilungen der Gesellschaft der Geologie und Bergbaustudenten, Innsbruck, 21, 745-776.

Larsen, G., Christensen, O. B., Bang, I. \& Buch, A. 1968. Qresund. Helsinger-Hälsingborg Linien. Geologisk Rapport. Danmarks geologiske Undersagelse, Rapport 1, Copenhagen, 90 pp, 24 pls.

Liboriussen, J., Ashton, P. \& Tygesen, T. 1987. The tectonic evolution of the Fennoscandian Border Zone in Denmark. Tectonophysics, Amsterdam, 137, 21-29.

Lund, J. J. 1977. Rhaetic to lower Liassic palynology of the onshore south-eastern North Sea Basin. Danmarks geologiske Undersogelse Rk. II, Copenhagen, 109, 1-129.

Lund, J. J. \& Pedersen, K. R. 1985. Palynology of the marine Jurassic formations in the Vardekløft ravine, Jameson Land, East Greenland. Bulletin of the geological Society of Denmark, Copenhagen, 33 (3-4), 371-399.

Løfaldli, M. \& Nagy, J. 1980. Foraminiferal stratigraphy of Jurassic deposits on Kongsøya, Svalbard. Norsk Polarinstitutts Skrifter, Oslo, 172, 63-95.

Meldgaard, S. \& Knudsen, K. L. 1979. Metoder til indsamling og oparbejdning af prøver til foraminifer-analyser. Dansk Natur-Dansk Skole, Arsskrift 1979, Copenhagen, 48-57

Michelsen, O. 1975. Lower Jurassic biostratigraphy and ostracods of the Danish Embayment. Danmarks geologiske Undersogelse Rk. II. Copenhagen, 104, 1-287.

Michelsen, O. 1978. Stratigraphy and distribution of Jurassic deposits of the Norwegian-Danish Basin. Danmarks geologiske Undersegelse, Serie B, Copenhagen, 2, 1-28.

Michelsen, O. 1989 a. Revision of the Jurassic lithostratigraphy of the Danish Subbasin. Danmarks geologiske Undersogelse, Serie A, Copenhagen, 24, 1-22.

Michelsen, O. 1989 b. Log-sequence analysis and environmental aspects of the Lower Jurassic Fjerritslev Formation in the Danish Subbasin. Danmarks geologiske Undersagelse, Serie A, Copenhagen, 25, 1-23.

Michelsen, O. \& Nielsen, L. H. 1991. Well records on the Phanerozoic stratigraphy in the Fennoscandian Border Zone, Denmark. Danmarks geologiske Undersogelse, Serie A, Copenhagen, 29, 1-37.

Nagy, J. 1985 a. Jurassic foraminiferal facies in the Statfjord area, Northern North Sea -I. Journal of Petroleum Geology,
Accrington, 8 (3), 273-295.

Nagy, J. 1985 b. Jurassic foraminiferal facies in the Statfjord area, Northern North Sea -II. Journal of Petroleum Geology, Accrington, 8 (4), 389-404.

Nagy, J., Dypvik, H. \& Bjaerke, T. 1984. Sedimentological and paleontological analyses of Jurassic North Sea deposits from deltaic environments. Journal of Petroleum Geology, Accrington, 7 (2), 169-188.

Nagy, J., Pilskog, B. \& Wilhelmsen, R. M. 1990. Facies controlled distribution of Foraminifera in the Jurassic North Sea Basin. In Hemleben, C., Kaminski, M. A., Kuhnt, W., \& Scott, D. B. (Eds.), Paleoecology, Biostratigraphy, Paleoceanography and Taxonomy of Agglutinated Foraminifera, 621-657. Kluwer Academic Publishers, Dordrecht.

Nielsen, O. B. 1992. Lithologi, lithostratigrafi og aflejringsmiljø i Anholtboringen. Dansk Geologisk Forening, Arsskrift for 19901991, Copenhagen, 62-67. (English abstract).

Norling, E. 1970. Jurassic and Lower Cretaceous stratigraphy of the Rydeb ck-Fortuna borings in southern Sweden. Geologiska Föreningens i Stockholm Förhandlingar, Stockholm, 92, 261-287.

Norling, E. 1972. Jurassic stratigraphy and foraminifera of western Scania, southern Sweden. Sveriges geologiska Undersökning, Serie $\mathrm{Ca}$, Stockholm, 47, 1-120.

Nørvang, A. 1957. The foraminifera of the Lias series in Jutland, Denmark. Meddelelser fra Dansk Geologisk Forening, Copenhagen, 13 (5), 1-413.

Poulsen, N.E. 1992. Jurassic dinoflagellate cyst biostratigraphy of the Danish Subbasin in relation to sequences in England and Poland; a preliminary review. Review of Palaeobotany and Palynology 75, 20 pp.

Poulsen, N.E. Gudmundson, L., Hansen, J.M. \& Husfelt, Y. 1990. Palynological preparation techniques, a new macerationtank-method and other modifications. Danmarks geologiske Undersøgelse, Serie. C, Copenhagen, 10, $22 \mathrm{pp}$.

Riding, J.B. 1983. The palynology of the Aalenian (Middle Jurassic) sediments of the Jackdaw Quarry, Stanway Hill, Gloucestershire, England. Mercian Geologist, Nottingham, 9, 111-120.

Riding, J.B., Walton, W. \& Shaw, D. 1991. Toarcian to Bathonian (Jurassic) palynology of the Inner Hebrides, northwest Scotland. Palynology 15, 115-179.

Riding, J.B. \& Thomas, J.E. 1992. Dinoflagellate cysts of the Jurassic System. In Powell, A.J. (ed.), A Stratigraphic Index of Dinoflagellate Cysts, 7-98. British Micropalaeontological Society Publication Series. Chapman and Hall, London 290 pp.

Schulz, E. 1967. Sporenpal ontologische Untersuchungen zur Rhät-Lias-Grenze in Thüringen und der Altmark. Geologie, Berlin, 11, 308-320.

Sorgenfrei, T. \& Buch, A. 1964. Deep tests in Denmark, 19351959. Danmarks geologiske Undersogelse, Rk. III, Copenhagen, 36, 1-146.

Tappan, H. 1980. The Paleobiology of Plant Protists. W. H. Freeman \& Co., San Francisco, 1028 pp.

Traverse, A. \& Ginsburg, R.N. 1966. Palynology of the surface sediments of Great Bahama Bank, as related to water movement and sedimentation. Marine Geology, Amsterdam, 4 417-459.

Woollam, R. \& Riding, J. B. 1983. Dinoflagellate cyst zonation of the English Jurassic. Institute of Geological Sciences Report, London, 83/2, $42 \mathrm{pp}$.

Spores and pollen

Acanthotriletes varius Nilsson, 1958 


\section{Table 1.}

Palynomorph and foraminiferal taxa recorded from the Jurassic section penetrated by the Anholt borehole, with author attributions and dates.

Alisporites microsaccus (Couper) Pocock, 1962

A. radialis (Leschik) Lund 1977

A. robustus Nilsson, 1958

A. thomasii (Couper) Nilsson, 1958

Anapiculatisporites spiniger (Leschik) Schulz, 1962

A. sp.

Aratrisporites minimus Schulz, 1967

A. sp.

Araucariacites australis Cookson, 1947

Baculatisporites comaumensis (Cookson) Potonié, 1956

B. sp.

Bisaccates indeterminate

Calamospora tener Leschik, 1955 emend. M ädler, 1964

Callialasporites dampieri (Balme) Dev, 1961

C. microvelatus Schulz, 1966

C. minus (Tralau) Guy, 1971

C. segmentatus (Balme) Srivastava, 1963

C. turbatus (Balme) Schulz, 1967

Campenia gigas Mädler, 1963

Camarozonosporites rudis (Leschik) Klaus, 1963

Cerebropollenites macroverrucosus (Thiergart) Schulz, 1967

C. thiergartii Schulz, 1967

Chasmatosporites apertus Nilsson, 1958

C. elegans Nilsson, 1958

C. hians Nilsson, 1958

C. major Nilsson, 1958

Chomotriletes minor (Kedves) Pocock, 1970

Cibotiumspora jurienensis Filatoff, 1975

Clavatipollenites hughesii Couper, 1958 sensu Schulz, 1967

Conbaculatisporites mesozoicus Klaus, 1960

C. spinosus (Mädler) Lund, 1977

Converrucosisporites sp.

Corollina meyeriana (Klaus) Venkatachala \& Góczán, 1964

C. torosus Traverse, 1975

Cyathidites sp.

Cypressacites sp.

Deltoidospora minor (Couper) Pocock, 1970

D. toralis (Leschik) Lund, 1977

D. sp. cf. D. minor (Couper) Pocock, 1970

Densoisporites scanicus Tralau, 1968

D. velatus Weyland \& Krieger, 1953

Dicyclosporis radiatus (Schulz) Jansonius \& Hills, 1990

Eucommindites minor Groot \& Penny, 1960

E. troedssonii Erdtmann, 1948

Exesipollenites tumulus Balme, 1957

Foraminisporis jurassicus Schulz, 1967

Gleicheniidites conspiciendus (Bolchovitina) Krutzsch, 1959

G. senonicus Ross, 1949

Iraqispora labrata Singh, 1964

Ischyosporites variegatus (Couper) Schulz, 1967

Kekryphalospora distincta Fenton \& Riding, 1987

Klukisporites lacunus Filatoff, 1975

Kraeuselisporites reissingeri (Harris) Morbey, 1975

Laevigatosporites dubius Nilsson, 1958

L. mesozoicus Schulz, 1967

Leptolepidites bossus (Couper) Schulz, 1967

L. macroverrucatus Schulz, 1967
L. major Couper, 1958

L. sp.

Limbosporites Iundbladii Nilsson, 1958

Lycopodiacidites rugulatus (Couper) Schulz, 1967

Lygodiosporites perverrucatus Couper, 1958

Manumia delcourtii (Pocock), Dybkjaer, 1991

Marattisporites scabratus Couper, 1958

Matonisporites crassiangulatus (Balme) Levet-Carette, 1964

"Monosaccates": Paleopicea glaesaria Bolkhovitina, 1956

Monosulcites minus Cookson, 1947

M. punctatus Orlowska-Zwolinska, 1966

Neoraistrickia sp.

Parvisaccites sp.

Peltandripites sp. cf. P. tener Norris, 1969

Perinopollenites elatoides Couper, 1958

P. sp. cf. P. elatoides Couper, 1958

Perotriletes sp.

Pinuspollenites minimus (Couper) Kemp, 1970

Podocarpidites spp.

Polycingulatisporites circulus Simoncsics \& Kedves, 1961

P. liassicus Schulz, 1967

Quadraeculina anellaeformis Malyavkina, 1949

Retitriletes austroclavatidites (Cookson) Potonié, 1956

R. clavatoides (Couper) Döring Krutzsch, Mai \& Schulz, 1963

$R$. semimuris (Danzé-Corsin et Laveine) McKellar, 1974

R.sp.

Retusotriletes mesozoicus Klaus, 1962

Rogalskaisporites cicatricosus (Rogalska) Danzé-Corsin \& Laveine, 1963

Schismatosporites ovalis Nilsson, 1958

Sculptisporis aulosenensis (Schulz) Koppelhus, 1991

Semiretisporites sp.

Sestrosporites pseudoalveolatus (Couper) Dettmann, 1963

Spheripollenites psilatus Couper, 1958

S. subgranulatus Couper, 1958

Staplinisporites caminus (Balme) Pocock, 1970

Stereisporites antiquasporites (Wilson \& Webster) Dettmann 1963

S. stereoides (Potonié \& Venitz) Pflug in Thomson \& Pflug, 1953

Striatella jurassica Mädler, 1964

S. paria (Li \& Shang) Filatoff \& Price, 1988

S. seehergensis Mädler, 1964

Taurocusporites verrucatus Schulz, 1967

Todisporites major Couper, 1958

T. minor Couper, 1958

Trachysporites asper Nilsson, 1958

T. sp.

Tripartina variabilis Malyavkina, 1949

Uvaesporites argenteaeformis (Bolkhovitina) Schulz, 1967

U. sp. cf. U. microverrucatus Schulz, 1967

Verrucosisporites obscurilaesuratus Pocock, 1962

Vitreisporites pallidus (Reissinger) Nilsson, 1958

\section{Megaspores}

Aneuletes patera Harris, 1961

Cabochonicus carbunculus (Dijkstra) Batten \& Ferguson, 1987

Echitriletes hispidus Marcinkiewicz, 1960 
Erlansonisporites sp.

Horstisporites sp.

Hughesisporites variabilis Dettmann, 1961

Paxillitriletes sp.

Striatriletes excavatus (Marcinkiewicz, 1962) Sweet, 1979

S. sulcatus (Dijkstra) Potonié, 1956

\section{Microplankton}

Acanthomorphitae spp.

Botryococcus spp.

Crassosphaera hexagonalis Wall, 1965

Cymatiosphaera pachytheca Eisenack, 1957

C. spp.

Lecaniella foveata Singh, 1971

Leiosphaeridia spp. (reworked).

Luehndea spinosa Morgenroth, 1970

Mendicodinium reticulatum Morgenroth, 1970

Micrhystridium sp.

Nannoceratopsis gracilis Alberti emend. van Helden, 1977

N. senex van Helden, 1977

N. sp. 1 (N. ridingii Poulsen, in press)

N. triangulata Prauss, 1987

N. triceras Drugg, 1978

Ovoidites spp.

Pterospermella sp.

Tasmanites sp.
Tetraporina compressa Kondratev, 1963

Veryhachium sp.

\section{Foraminifera}

Ammobaculites agglutinans (d'Orbigny, $1846=$ Spirolina agglutinans)

Ammobaculites aff. alaskensis Tappan, 1955

Ammobaculites vetustus (Terquem \& Berthelin, $1875=$ Haplophragmium vetustum)

Astacolus varians (Bornemann, $1854=$ Cristellaria varians)

Bulbobaculites oviloculus (Nagy, 1991 = Bulbobaculites oviloculus)

Bulbobaculites sp. 1

Eoguttulina liassica (Strickland, $1846=$ Polymorphina liassica)

Haplophragmoides aff. pygmaeus (Haeusler, $1881=$ Rotalia pygmaea)

Kutsevella sp. 1

Kutsevella sp. 2

Planularia beierana (Gümbel, $1862=$ Marginulina beierana)

Prodentalina vetusta (d'Orbigny, $1849=$ Dentalina vetusta)

Reophax helvetica (Haeusler, $1881=$ Dentalina helvetica)

Spirillina numismalis Terquem \& Berthelin, 1875

Trochammina sp. 